\title{
Stability-Indicating Methods for the Determination of Ornidazole in The Presence of its Degradate According to ICH Guidelines
}

\author{
Fatma I Khattab, Nesrin K Ramadan, Maha A Hegazy* and Nermine S Ghoniem \\ Analytical Chemistry Department, Faculty of Pharmacy, Cairo University, Kasr el Aini Street, 11562, Cairo, Egyp
}

\begin{abstract}
Four simple, sensitive, selective and precise methods were developed for the determination of Ornidazole (OZ) in presence of its degradation product. The first method was based on first derivative spectrophotometry $\mathrm{D}^{1}$ and measuring the peak amplitude of $\mathrm{D}^{1}$ spectra at 290.4 and $332 \mathrm{~nm}$. The second method was depended on measuring the peak amplitude of the first derivative of the ratio spectra DD ${ }^{1}$ at 288.5 and $328 \mathrm{~nm}$. The third method was the mean centering of the ratio spectra one (MCR), which allowed the determination of OZ in presence of its degradate and the concentration of $\mathrm{OZ}$ was determined by measuring the amplitude at $312.8 \mathrm{~nm}$. Separation and determination of OZ by HPLC in the forth method was achieved using Lichrosorb RP-18 column and acetonitrile: water, (50:50 $\mathrm{v} / \mathrm{v}), 0.2 \%$ triethylamine, the $\mathrm{pH}$ was adjusted to 4 using o-phosphoric acid. The flow rate was $1 \mathrm{~mL} \mathrm{~min}^{-1}$. Beer's law was obeyed in concentration range $5-30 \mu \mathrm{g} / \mathrm{ml}$ for the first three methods. The linearity range in the forth method was $2-20 \mu \mathrm{g} / \mathrm{ml}$. The proposed methods were used to determine OZ in its pure powdered form with mean percentage recoveries of $99.86 \pm 1.249 \%$ and $99.98 \pm 0.868 \%$ for OZ at 290.4 and $332 \mathrm{~nm}$ respectively, in $\mathrm{D}^{1}$ method. In $D^{1}$ method, the mean percentage recoveries were $100.11 \pm 1.020 \%$ and $100.15 \pm 1.043 \%$ at 288.5 and $328 \mathrm{~nm}$ respectively. While in MCR and HPLC methods, the mean percentage recoveries were $100.09 \pm 0.387 \%$ and $100.00 \pm 1.302 \%$ respectively. The degradation product was obtained in alkaline stress condition, separated, and identified by LC-MS spectral analysis, from which the degradation product was confirmed. The four methods were validated according to International Conference on Harmonization. The four methods were found to be specific for OZ in presence of up to $80 \%$ of its degradation product in the first three methods. The four proposed methods were successfully applied for the determination of $\mathrm{OZ}$ in Tibezole ${ }^{\circledR}$ tablets. Statistical comparison between the results obtained by these methods and the reported method for the determination of the drug in its pharmaceutical formulation was done, and it was found that there was no significant difference between them.
\end{abstract}

Keywords: Orindazole; Derivative; Ratio derivative; Mean centering spectrophotometry; HPLC

\section{Introduction}

It is considered as antibacterial and antiprotozoal. OZ (Figure 1a) is converted into an active form by reduction of its nitro group, this binds to DNA and prevent nucleic acid formation; it is a bacteriostatic $[1,2]$. Ornidazole used for treatment of bacterial vaginosis, trichomoniasis, genitourinary infections in women and men due to Trichomonas vaginalis, amoebiasis (all intestinal infections due to Entamoeba histolytica, including amoebic dysentery, all extra intestinal forms of amoebiasis, especially amoebic liver abscess), Giardiasis (lambliasis). It is also used in infections due to anaerobic bacteria (such as septicaemia, meningitis, peritonitis, postoperative wound infections, puerperal sepsis, septic abortion, and endometritis). OZ also used in the treatment of prophylaxis during surgical interventions, particularly those involving the colon, and in gynaecological operations [2].

Many analytical methods were reported for detection and determination of ornidazole in bulk powder, pharmaceutical formulations alone or in combination with other drugs and/or in<smiles>Cc1ncc([N+](=O)[O-])n1CCO</smiles>

Molecular formula $=\mathrm{C} 6 \mathrm{H} 9 \mathrm{~N} 3 \mathrm{O} 3$; Molecular weight $=171.15$

Figure 1a: Structure of Orindazole. biological fluids using titremetry [3], spectrophotometry [4-6], HPLC [7-15], HPTLC [16,17], GC [18], voltammetry [19-21] and Chemiluminescent method [22]. None of the reported methods was concerned with the determination of the intact drug in presence of its degradation product. This paper presents a study of alkaline, acidic, oxidative, thermal and photo degradation of $\mathrm{OZ}$, followed by the development of 4 stability-indicating procedures for the determination of the drug in its pure form, in presence of its degradate and in tablet formulations. The scientific novelty of the present work is that the methods used are simple, rapid, and selective. The focus of the present study was to develop and validate different methods for the determination of $\mathrm{OZ}$ in its tablets dosage form.

\section{Experimental}

\section{Instrumentation}

- A double beam UV-visible spectrophotometer (SHIMADZU,

*Corresponding author: Maha A Hegazy, Analytical Chemistry Department Faculty of Pharmacy, Cairo University, Kasr el Aini Street, 11562, Cairo, Egypt E-mail: mahahgazy@yahoo.com

Received January 26, 2012; Accepted October 27, 2012; Published October 30 2012

Citation: Khattab FI, Ramadan NK, Hegazy MA, Ghoniem NS (2012) StabilityIndicating Methods for the Determination of Ornidazole in The Presence of its Degradate According to $\mathrm{ICH}$ Guidelines. Pharmaceut Anal Acta 3:179. doi:10.4172/2153-2435.1000179

Copyright: (C) 2012 Khattab Fl, et al. This is an open-access article distributed under the terms of the Creative Commons Attribution License, which permits unrestricted use, distribution, and reproduction in any medium, provided the original author and source are credited. 
Japan) model UV-1601 PC with quartz cell of $1 \mathrm{~cm}$ path length, connected to IBM compatible computer. The software was UVPC personal spectroscopy software version 3.7. The spectral bandwidth was $2 \mathrm{~nm}$ and wavelength-scanning speed $2800 \mathrm{~nm} /$ $\min$.

- UV-lamp with short wavelength $254 \mathrm{~nm}$ (USA).

- An Agilent 1100 series HPLC instrument (Agilent,Waldbronn, Germany), with an isocratic pump model G 1310 A pump; (Agilent, Waldbronn, Germany), connected with UV-Visible spectrophotometric detector model G 1314 A, set at $311 \mathrm{~nm}$, (Agilent, Waldbronn, Germany), Injection was performed with a A Rheodyne injector model 7225/7725I, (Rohnert park, CA., USA) equipped with $20 \mu \mathrm{l}$ injector and Hamilton syringe $(100 \mu \mathrm{l})$. The instrument was connected to an IBM compatible PC, bundled with Merck- Hitachi model D-7000 HPLC System Manager Chromatography Data Station Software, HP 800 inkjet printer, and Lichrosorb RP-18 (250 mm $\times 4.6 \mathrm{~mm}$ i.d $)$ column particle size $(5 \mu \mathrm{m})$; (USA).

\section{Reference sample}

Ornidazole (OZ) pure sample was kindly supplied by El PharoniaPharmaceuticals, New Borg El-Arab City, Alexandria, A.R.E; it was certified to contain $99.90 \% \mathrm{w} / \mathrm{w}$ according to the manufacturer's method.

\section{Pharmaceutical formulation}

Tibezole Tablets, batch no. 1319003, are labeled to contain $500 \mathrm{mg}$ $\mathrm{OZ}$ and were manufactured by El Pharonia-Pharmaceuticals, New Borg El-Arab City, Alexandria, A.R.E. and obtained from the local market.

\section{Degraded sample}

Degraded OZ sample (OZ Deg) was prepared by accurately weighing $50 \mathrm{mg}$ of $\mathrm{OZ}$ pure sample, refluxed with $50 \mathrm{~mL} 0.5 \mathrm{~N}$ $\mathrm{NaOH}$ for 15 minutes and neutralized with $1 \mathrm{~N} \mathrm{HCl}$, then transferred quantitatively to $100-\mathrm{mL}$ measuring flask and the volume completed to the mark with methanol. Complete degradation was confirmed by TLC using methanol: chloroform: ether (1:3:9 by volume) as the mobile phase.

\section{Reagents}

Methanol, Ether, Chloroform (Prolapo, VWR, international, West Chester, PA), Sodium hydroxide, Hydrochloric acid (Merck, Dramstadt, Germany), Acetonitrile: HPLC grade, (Merck, Darmstadt, Germany), Water for HPLC and Orthophosphoric acid: HPLC grade.

\section{Standard solutions}

- Stock standard solution of $\mathrm{OZ}$ in the concentration of 0.5 $\mathrm{mg} \mathrm{mL} \mathrm{m}^{-1}$ for $\mathrm{D}^{1}, \mathrm{DD}^{1}, \mathrm{MCR}$ and HPLC methods. Prepared by accurately weighing $50 \mathrm{mg}$ of OZ into $100-\mathrm{mL}$ measuring flask and completing the volume with methanol.

- Stock solution of OZ Deg in the concentration of $0.5 \mathrm{mg} \mathrm{mL}^{-1}$ for $\mathrm{D}^{1}, \mathrm{DD}^{1}, \mathrm{MCR}$ and HPLC methods. Prepared by accurately weighing $50 \mathrm{mg}$ of OZ Deg into $100-\mathrm{mL}$ measuring flask and completing the volume with methanol.

- Working standard solution of $\mathrm{OZ}$ and working solution of $\mathrm{OZ}$ Deg in the concentration of $0.05 \mathrm{mg} \mathrm{mL}^{-1}$ for $\mathrm{D}^{1}, \mathrm{DD}^{1}, \mathrm{MCR}$ and HPLC methods. Prepared by an additional dilution of the respective stock solutions with methanol.

\section{Laboratory prepared mixtures containing different ratios of $\mathrm{OZ}$ and its degradation product for $\mathrm{D}^{1}, \mathrm{DD}^{1}$ and $\mathrm{MCR}$ methods}

Aliquots $(5.4-1.2 \mathrm{~mL})$ of $\mathrm{OZ}$ equivalent to $270-60 \mu \mathrm{g}$ were accurately transferred from its working standard solution $(0.05 \mathrm{mg} \mathrm{mL}$ $\left.{ }^{1}\right)$ into a set of $10-\mathrm{mL}$ measuring flasks to which aliquots $(1.2-5.4 \mathrm{~mL})$ of OZ Deg equivalent to $60-270 \mu \mathrm{g}$ from its working solution $(0.05 \mathrm{mg}$ $\left.\mathrm{mL}^{-1}\right)$ were accurately added. The volumes were then completed with methanol to prepare mixtures containing from $10-80 \%$ of OZ Deg.

\section{Procedures}

Construction of the calibration graphs for $\left(D^{1}\right),\left(D^{1}\right),(M C R)$ and HPLC methods for $\mathrm{D}^{1}$ method: aliquots of $\mathrm{OZ}$ working standard solution $\left(0.05 \mathrm{mg} \mathrm{mL}^{-1}\right)$ equivalent to $50-300 \mu \mathrm{g} \mathrm{mL}^{-1}$ were accurately transferred into a series of $10-\mathrm{mL}$ measuring flasks and the volume was completed to the mark with methanol. The prepared solutions were scanned against methanol and the first derivative spectra $\left(\mathrm{D}^{1}\right)$ of the scanned spectra were recorded using $\Delta \lambda=4$ and scaling factor $=10$. Calibration curves were then constructed by plotting the values of the peak amplitude of $\mathrm{D}^{1}$ spectra at 290.4 and $332 \mathrm{~nm}$ (corresponding to zero absorbance of degradate) versus the corresponding concentrations and the regression parameters were computed.

For $\mathrm{DD}^{1}$ method: The zero-order spectra of the prepared solutions were divided by a standard spectrum of $25 \mu \mathrm{g} \mathrm{mL} \mathrm{m}^{-1} \mathrm{OZ}$ Deg and the first derivative of the ratio spectra $\left(\mathrm{DD}^{1}\right)$ were then obtained with $\Delta \lambda=4$ and scaling factor $=10$. Calibration curves were constructed by plotting the peak amplitude at 288.5 and $328 \mathrm{~nm}$ versus the corresponding concentrations of $\mathrm{OZ}$ and the regression parameters were computed.

For MCR method: The zero-order spectra of the prepared solutions were scanned in the range of 200-400 $\mathrm{nm}$. The scanned spectra of OZ were divided by the normalized absorption spectrum of OZ Deg and the obtained ratio spectra were then mean centered. The calibration curve for OZ was constructed by plotting the mean centered values at $312.8 \mathrm{~nm}$ versus the corresponding concentrations of $\mathrm{OZ}$.

For HPLC method: Aliquots (0.4-4.0 ml) of OZ working standard solution $\left(0.05 \mathrm{mg} \mathrm{mL}^{-1}\right)$ equivalent to $20-200 \mu \mathrm{g}$, were accurately transferred into set of 10-mL measuring flasks and the volume was then completed to the mark with the mobile phase. Using a $100-\mu \mathrm{L}$ syringe, a $20-\mu \mathrm{L}$ volume of each solution was injected in triplicate into the liquid chromatography at ambient temperature under the following chromatographic conditions:

- Stationary phase: Lichrosorb RP-18 column $(250 \mathrm{~mm} \times 4.6 \mathrm{~mm}$ I.D), particle size is $5 \mu \mathrm{m}$.

- Mobile phase: acetonitrile: water, (50:50 v/v), $0.2 \%$ triethylamine, the $\mathrm{pH}$ was adjusted to 4 using o-phosphoric acid (The mobile phase was filtered using $0.45 \mu \mathrm{m}$ membrane filters and degassed by ultrasonic vibrations for 30 minutes prior to use).

- Flow rate: $1 \mathrm{~mL} / \mathrm{min}$.

- Wavelength: $311 \mathrm{~nm}$.

- The sensitivity: was set at 0.001 AUFS.

- Column temperature: $25^{\circ} \mathrm{C}$

A linear calibration curve was constructed for OZ relating the relative peak area (calculated following the external standard technique 
using an external standard of $6 \mu \mathrm{g} \mathrm{mL} \mathrm{m}^{-1}$ ) of $\mathrm{OZ}$, to the corresponding concentrations, and the corresponding regression equation was computed.

Application of the proposed methods for the analysis of laboratory prepared mixtures of intact drug and its degradation product for $\left(\mathrm{D}^{1}\right),\left(\mathrm{DD}^{1}\right)$ and $(\mathrm{MCR})$ methods

The absorption spectra of the laboratory prepared mixtures were recorded. Then the procedures were completed as described under construction of the calibration graphs. The concentrations of $\mathrm{OZ}$ were calculated by substituting in the corresponding regression equation.

\section{Application of the four proposed methods to the analysis of $\mathrm{OZ}$ in pharmaceutical preparation}

Twenty Tibezole tablets [labeled to contain $500 \mathrm{mg}$ OZ] were accurately weighed and finely powdered. An accurate weight of the powdered tablets equivalent to $50 \mathrm{mg}$ of $\mathrm{OZ}$ was transferred into a $100-\mathrm{mL}$ measuring flask and extracted with $50 \mathrm{~mL}$ methanol in an ultrasonic bath for $30 \mathrm{~min}$., diluted to volume with the same solvent and filtered. Suitable dilutions were made using methanol to prepare a tablet solution containing $10 \mu \mathrm{g} \mathrm{mL} \mathrm{m}^{-1} \mathrm{OZ}$, then the procedure was completed as described under construction of the calibration graphs. The concentrations of $\mathrm{OZ}$ were calculated from the corresponding regression equation.

\section{Results and Discussion}

By reviewing the reported stress stability testing of OZ as stated by the ICH guidelines, Monika et al. proved that $\mathrm{OZ}$ is liable to acid, alkaline, oxidative and photo degradation.

In this work, we were concerned with the alkaline degradation of $\mathrm{OZ}$ as it is completely degraded under very mild conditions.

Upon trying the previously reported conditions for alkaline degradation $(0.1 \mathrm{~N} \mathrm{NaOH}$ at zero time) [9] the drug is not completely degraded as confirmed by TLC [using methanol: chloroform: ether ((1:3:9) by volume) as the mobile phase.

So, several trials have been made to obtain complete hydrolysis of $\mathrm{OZ}$ and it was found that upon refluxing with $0.5 \mathrm{~N} \mathrm{NaOH}$ at $80^{\circ} \mathrm{C}$, complete degradation occurred after 15 minutes and the degradation process was followed by TLC.

In the present work and according to Salman and Sümer [23] the alkaline hydrolysis of $\mathrm{OZ}$ resulted in the removal of the nitro group and furthermore losing its pharmacological antibacterial activity [1], thus it was of a potential task to develop different stability indicating methods.

This was confirmed by treating the cooled degradate solution with standard sulfanilamide, the violet color produced indicated the presence of the nitrite ions in the solution. Also the spectrum of the degradation product showed the disappearance of the conjugation caused by the nitro group which resulted in the disappearance of its $\lambda_{\max }$ (Figure 2), further more the degradation products were subjected to LC- MS analysis, (Figure 3), which clarify the disappearance of the molecular ion peak of the drug at $219 \mathrm{~m} / \mathrm{z}$ and the appearance of two new molecular ion peaks corresponding to the two degradates at 157 and $174 \mathrm{~m} / \mathrm{z}$, (Figure $1 \mathrm{~b}$ ).

Trials have been made to separate the two degradation products by TLC and HPLC, using several systems with different ratios and different flow rates in case of HPLC methods. Unsuccessful results

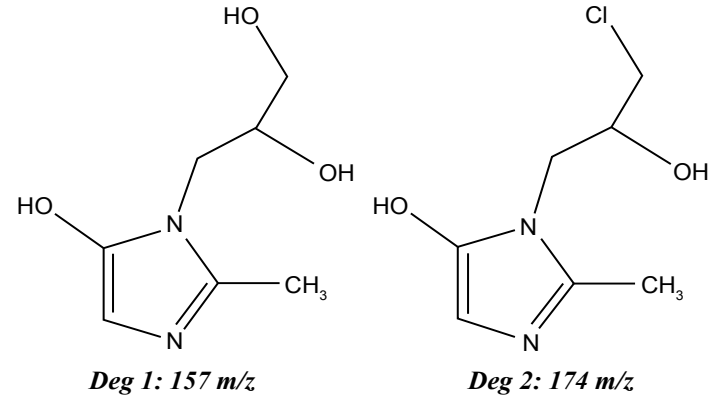

Figure 1b: Structure of Orindazole Degradation products $1 \& 2$.

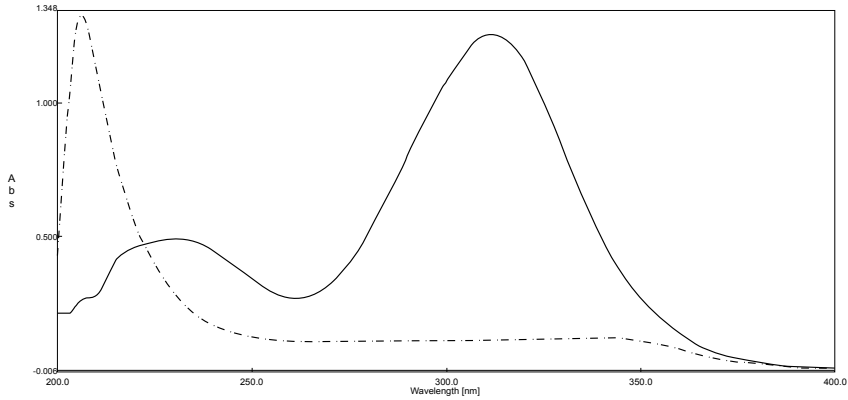

Figure 2: $\mathrm{D}^{0}$ of $30 \mu \mathrm{g} \mathrm{mL}^{-1}$ of $\mathrm{OZ}(-)$ and $\mathrm{OZ} \mathrm{Deg}(-. .-. \cdot)$ in methanol.

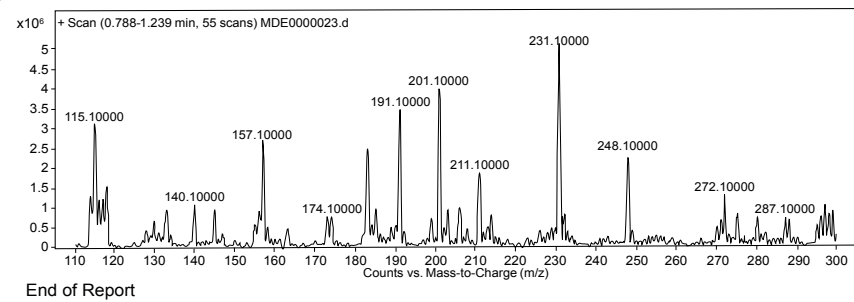

Figure 3: LC-Mass spectrum of OZ degradation product.

were obtained; therefore we consider the solution of the degradation as one product.

The degradation process was also monitored by HPLC [Column: C-18; mobile phase: water: acetonitrile (60:40 v/v); detection wavelength: $311 \mathrm{~nm}$; flow rate: $1 \mathrm{~mL} \mathrm{~min}^{-1}$ ] (Figures 4-7).

First-derivative $\left(D^{1}\right)$, first derivative of the ratio spectrum $\left(\mathrm{DD}^{1}\right)$ and mean centering of the ratio spectra (MCR) spectrophotometric methods

The zero-order spectra of $\mathrm{OZ}$ and its degradation product show an overlap, (Figure 2, that prevents the use of direct spectrophotometric analysis of the drug in the presence of its degradation product. In an attempt to resolve this overlap, derivative, derivative ratio and mean centering of the ratio spectra methods were applied. Upon examining the first derivative spectra of OZ and degradate, (Figure 8), it was noticed that OZ could be determined at $290.4 \mathrm{~nm}$ and $332 \mathrm{~nm}$, where degradate showing no interference.

Linearity of the peak amplitude at $290.4 \mathrm{~nm}$ and $332 \mathrm{~nm}$ with the concentrations of $\mathrm{OZ}$ was studied and calibration curves were constructed. 
The proposed procedure was found to be valid in the range of 5-30 $\mu \mathrm{g} \mathrm{mL}{ }^{-1}$, and the regression equations found to be:

$$
\begin{aligned}
& \mathrm{D}_{290.4}^{1}=0.0097 \mathrm{C}+0.0011 \mathrm{r}=0.9998 \\
& \mathrm{D}^{1}{ }_{332}=0.012 \mathrm{C}-0.0047 \mathrm{r}=0.9999
\end{aligned}
$$

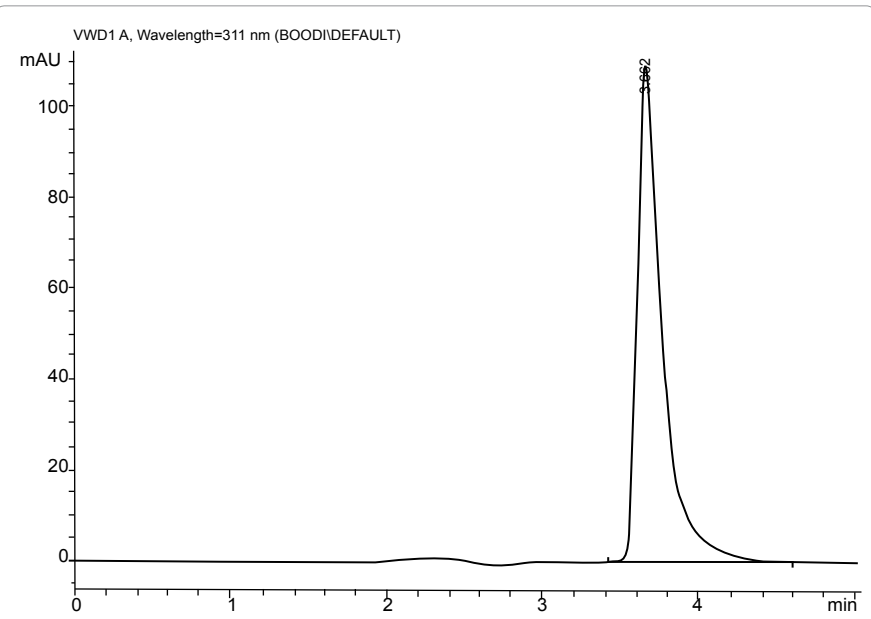

Figure 4: HPLC chromatogram of $10 \mu \mathrm{g} / \mathrm{ml} \mathrm{OZ} \mathrm{in} 0.5 \mathrm{M} \mathrm{NaOH}$, at zero minute.

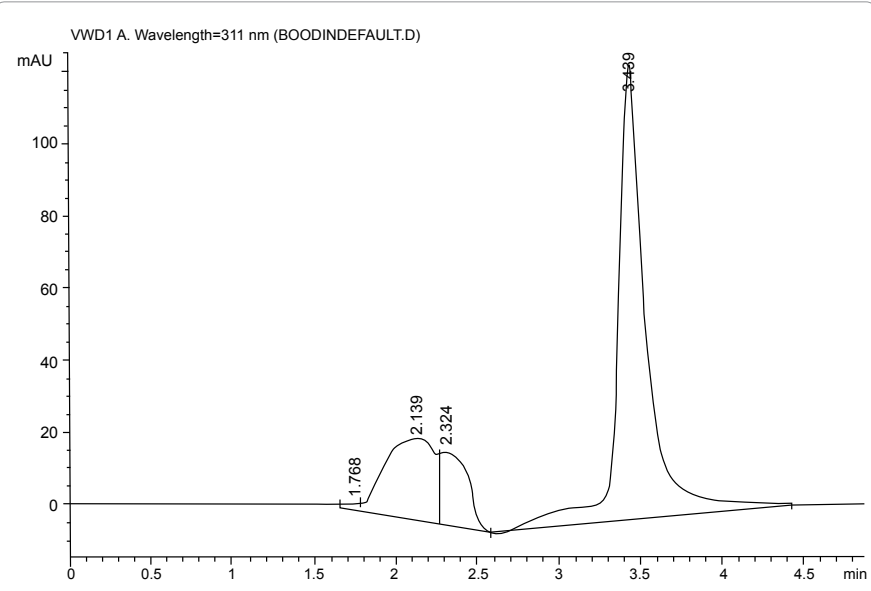

Figure 5: HPLC chromatogram of $10 \mu \mathrm{g} / \mathrm{ml} \mathrm{OZ}$ in $0.5 \mathrm{M} \mathrm{NaOH}$, after 5 minutes

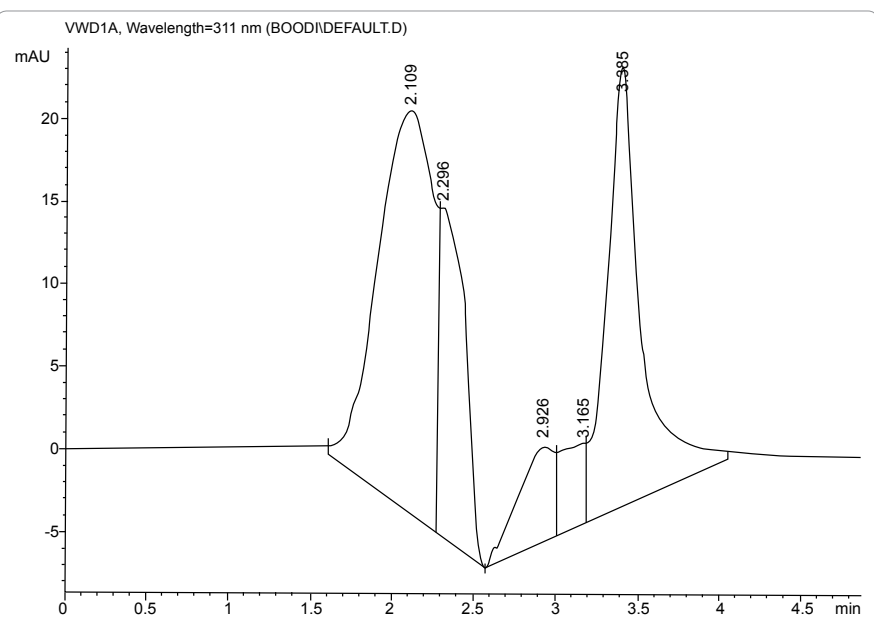

Figure 6: HPLC chromatogram of $10 \mu \mathrm{g} / \mathrm{ml} \mathrm{OZ}$ in $0.5 \mathrm{M} \mathrm{NaOH}$, after 10 minutes.

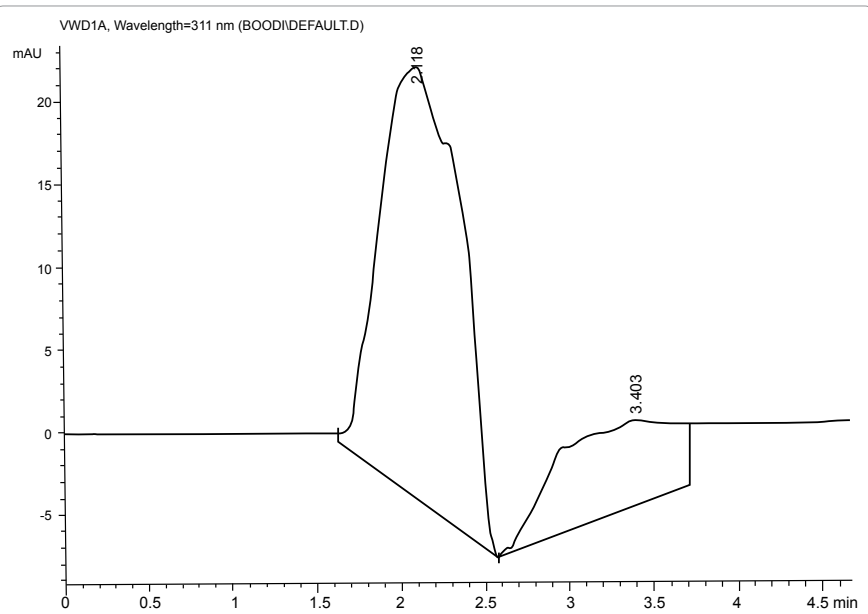

Figure 7: $\mathrm{HPLC}$ chromatogram of $10 \mu \mathrm{g} / \mathrm{ml} \mathrm{OZ}$ in $0.5 \mathrm{M} \mathrm{NaOH}$, after 15 minutes.

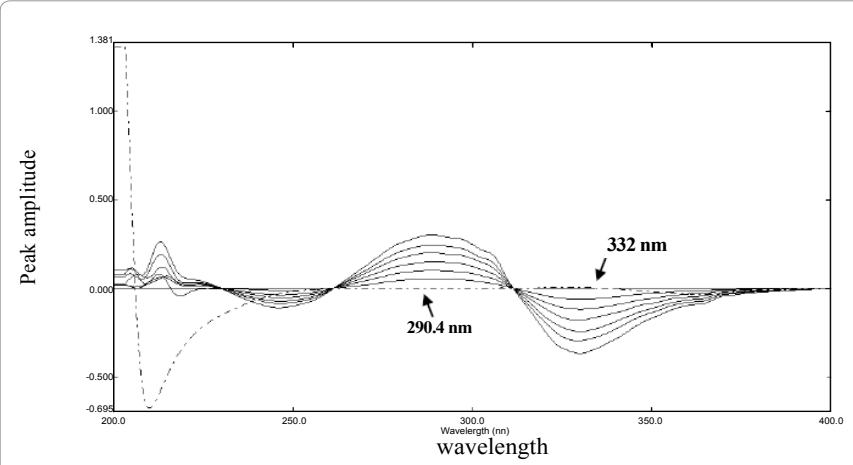

Figure 8: $\mathrm{D}^{1}$ of $\left(5-30 \mu \mathrm{gL}^{-1}\right)$ of $\mathrm{OZ}(-)$ and $30 \mu \mathrm{g} \mathrm{mL}^{-1}$ of $\mathrm{OZ} \mathrm{Deg} \mathrm{(-..-..)}$ in methanol.

Where, $\mathrm{D}^{1}{ }_{290.4}$ and $\mathrm{D}_{332}^{1}$ is the peak amplitudes at $290.4 \mathrm{~nm}$ and 332 $\mathrm{nm}$, respectively, $\mathrm{C}$ are the concentration of $\mathrm{OZ}$ in $\mu \mathrm{g} \mathrm{mL}^{-1}$ and $\mathrm{r}$ is the correlation coefficient.

The proposed method was successfully applied for the determination of $\mathrm{OZ}$ in its pure powdered form with mean percentage recovery of $99.86 \pm 1.249 \%$ and $99.98 \pm 0.868 \%$ at $290.4 \mathrm{~nm}$ and 332 $\mathrm{nm}$, respectively (Table 1 ).

Also, in order to achieve good resolution and remove this interference, $\mathrm{DD}^{1}$ method was established. The main advantage of this method is that the whole spectrum of the interfering substance is cancelled. In order to optimize $\mathrm{DD}^{1}$ method, several divisors were tested as 5,10,15, 20,25 and $30 \mu \mathrm{g} \mathrm{mL}^{-1}$ along with the normalized OZ Deg spectrum. The best results were obtained on using a standard spectrum of $25 \mu \mathrm{g} \mathrm{mL}^{-1} \mathrm{OZ}$ Deg as a divisor. The absorption spectra of $\mathrm{OZ}$ in the concentration range of $5-30 \mu \mathrm{g} \mathrm{mL}^{-1}$ were divided by the absorption spectrum of $25 \mu \mathrm{g} \mathrm{mL}^{-1} \mathrm{OZ}$ Deg to obtain the ratio spectra, (Figure 9), then the first derivative of the obtained ratio spectra were then calculated using $\Delta \lambda=4$ and scaling factor $=10$ as shown in Figure 10 .

$\mathrm{DD}^{1}$ values showed good linearity and reproducibility at 288.5 and $328 \mathrm{~nm}$, the corresponding regression equations were found to be:

$$
\begin{aligned}
& \mathrm{DD}_{288.5}^{1}=0.0992 \mathrm{C}-0.0015 \mathrm{r}=0.9998 \\
& \mathrm{DD}_{328}^{1}=0.1248 \mathrm{C}-0.0305 \mathrm{r}=0.9997
\end{aligned}
$$




\begin{tabular}{|c|c|c|c|c|c|c|}
\hline \multirow[t]{2}{*}{ Parameter } & \multicolumn{2}{|l|}{$\mathrm{D}^{1}$ method } & \multicolumn{2}{|l|}{$\mathrm{DD}^{1}$ method } & \multirow[t]{2}{*}{ MCN method } & \multirow[t]{2}{*}{ HPLC method } \\
\hline & $290.4 \mathrm{~nm}$ & $332 \mathrm{~nm}$ & $288.5 \mathrm{~nm}$ & $328 \mathrm{~nm}$ & & \\
\hline Range & \multicolumn{2}{|l|}{$\begin{array}{l}5-30 \mu \mathrm{g} \\
\mathrm{mL}^{-1}\end{array}$} & \multicolumn{2}{|l|}{$\begin{array}{l}5-30 \mu \mathrm{g} \\
\mathrm{mL}^{-1}\end{array}$} & $5-30 \mu \mathrm{g} \mathrm{mL}^{-1}$ & $2-20 \mu \mathrm{g} \mathrm{mL}^{-1}$ \\
\hline Slope & 0.0097 & 0.0120 & 0.0992 & 0.1248 & 0.0530 & 0.1334 \\
\hline Intercept & 0.0011 & -0.0047 & -0.0015 & -0.0305 & -0.0039 & -0.0318 \\
\hline SE of the slope & $8.463 \times 10^{-5}$ & $8.443 \times 10^{-5}$ & 0.0010 & 0.0014 & 0.0001 & 0.0009 \\
\hline SE of the intercept & 0.0016 & 0.0016 & 0.0193 & 0.0271 & 0.0021 & 0.0113 \\
\hline Correlation coefficient( $r$ ) & 0.9998 & 0.9999 & 0.9998 & 0.9997 & 1 & 0.9998 \\
\hline LOD & 0.5364 & 0.4345 & 0.6178 & 0.6894 & 0.1281 & 0.3884 \\
\hline LOQ & 1.6255 & 1.3167 & 1.8798 & 2.0889 & 0.3881 & 1.1769 \\
\hline Accuracy (mean \pm RSD \%) & $99.86 \pm 1.249$ & $99.98 \pm 0.868$ & $100.11 \pm 1.020$ & $100.15 \pm 1.043$ & $100.09 \pm 0.387$ & $100.00 \pm 1.302$ \\
\hline $\begin{array}{l}\text { Precision } \\
\text { Repeatability \% } \\
\text { Intermediate precision \% }\end{array}$ & $\begin{array}{l}0.847 \\
0.977\end{array}$ & $\begin{array}{l}0.853 \\
0.733\end{array}$ & $\begin{array}{l}0.508 \\
0.615\end{array}$ & $\begin{array}{l}0.582 \\
0.743\end{array}$ & $\begin{array}{l}0.631 \\
0.584\end{array}$ & $\begin{array}{l}0.935 \\
0.749\end{array}$ \\
\hline
\end{tabular}

Table 1: Validation parameters of the proposed method for the determination of OZ pure samples.

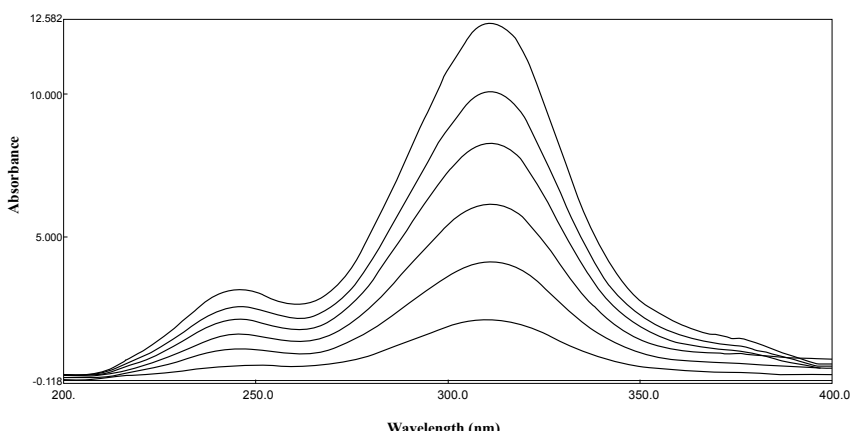

Figure 9: Zero order of ratio spectra of $(5-30 \mu \mathrm{g} \mathrm{mL}-1)$ of $\mathrm{OZ}$ using $25 \mu \mathrm{g} \mathrm{mL}$ of OZ Deg as a divisor.

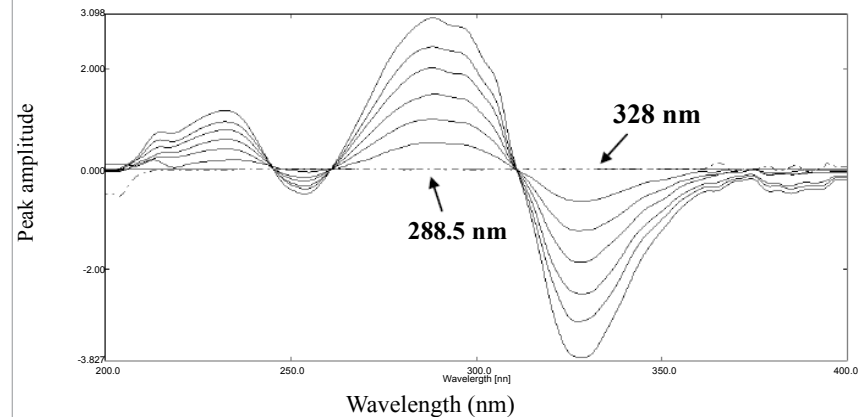

Figure 10: $\mathrm{DD}^{1}$ of $\mathrm{OZ}(-)\left(5-30 \mu \mathrm{g} \mathrm{mL}^{-1}\right)$ and $15 \mu \mathrm{g} \mathrm{mL}^{-1}$ of OZ Deg $(-. \cdot-.$.$) , in$ methanol, using $25 \mu \mathrm{g} \mathrm{mL}^{-1}$ of OZ Deg as a divisor.

Where, $\mathrm{DD}_{288.5}^{1}$ and $\mathrm{DD}_{328}^{1}$ are the peak amplitudes at $288.5 \mathrm{~nm}$ and $328 \mathrm{~nm}$, respectively, $\mathrm{C}$ is the concentration of $\mathrm{OZ}$ in $\mu \mathrm{g} \mathrm{mL} \mathrm{m}^{-1}$ and $r$ is the correlation coefficient.

The proposed method was successfully applied for the determination of $\mathrm{OZ}$ in its pure powdered form with mean percentage recoveries of $100.11 \pm 1.020 \%$ and $100.15 \pm 1.043 \%$ at $288.5 \mathrm{~nm}$ and 328 $\mathrm{nm}$, respectively (Table 1).

Also, mean centering method was applied to resolve this overlap so, for the determination of $\mathrm{OZ}$, the absorption spectra of the standard $\mathrm{OZ}$ solutions with different concentrations were recorded in the range of 200-400 nm, divided by the normalized OZ Deg spectrum and the ratio spectra were obtained (Figure 11).
The obtained ratio spectra were then mean centered and the concentration of $\mathrm{OZ}$ was determined by measuring the amplitude at $312.8 \mathrm{~nm}$ (corresponding to a maximum wavelength) (Figure 12).

The calibration curve relating the mean centered $(\mathrm{MCN})$ values at $312.8 \mathrm{~nm}$ to the corresponding concentrations of $\mathrm{OZ}$ was constructed. The proposed method was found to be valid in the concentration range of 5-30 $\mu \mathrm{g} \mathrm{mL}^{-1}$, and the regression equation was found to be:

$$
\mathrm{MCN}_{312.8}=0.053 \mathrm{C}-0.0039 \mathrm{r}=1
$$

Where, MCN is the mean centered values at $312.8 \mathrm{~nm}, \mathrm{C}$ is the concentration of $\mathrm{OZ}$ in $\mu \mathrm{g} \mathrm{mL}^{-1}$ and $\mathrm{r}$ is the correlation coefficient.

The effect of divisor concentration on the analytical parameters such as slope, intercept and correlation coefficient of the calibration graphs was also tested. Different concentrations of divisor were tested but it was observed that changing the concentration had no significant effect on their linear calibration range and the calculated analytical parameters. Therefore, a normalized spectrum of OZ Deg was used as a divisor spectrum in the proposed method.

The proposed method was successfully applied for the determination of $\mathrm{OZ}$ in its pure powdered form with mean percentage recovery of $100.09 \pm 0.387 \%$ (Table 1 ).

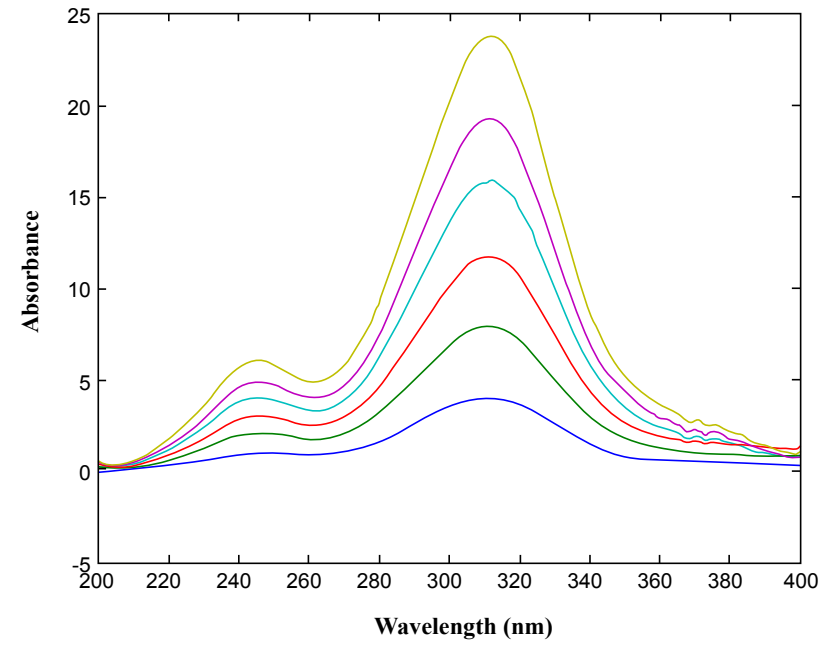

Figure 11: Ratio spectra of $\mathrm{OZ}\left(5-30 \mu \mathrm{g} \mathrm{m} \mathrm{m}^{-1}\right)$, using $\mathrm{OZ}$ Deg normalized spectrum as a divisor. 
Citation: Khattab FI, Ramadan NK, Hegazy MA, Ghoniem NS (2012) Stability-Indicating Methods for the Determination of Ornidazole in The Presence of its Degradate According to ICH Guidelines. Pharmaceut Anal Acta 3:179. doi:10.4172/2153-2435.1000179

Page 6 of 8

\section{HPLC method}

In this work, a RP-HPLC method is described for the determination of OZ in presence of OZ Deg without prior separation. This method aims to develop a simple stability indicating HPLC assay for the analysis of $\mathrm{OZ}$.

In order to optimize the proposed HPLC method, all the experimental conditions were investigated. Several trials were carried out to obtain good and optimum separation of OZ from its degradation products. Different composition mobile phases with different ratios were tried such as methanol: water $(50: 50, \mathrm{v} / \mathrm{v})$, and acetonitrile: water

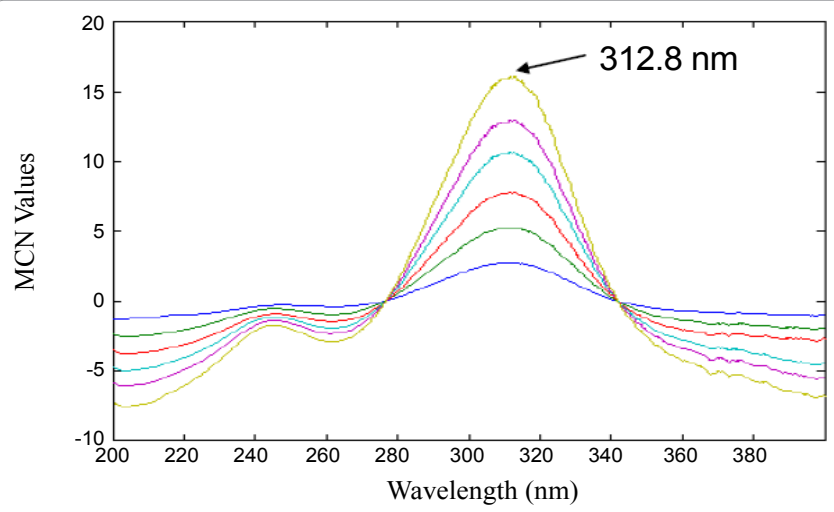

Figure 12: Mean centered ratio spectra of $\mathrm{OZ}\left(5-30 \mu \mathrm{g} \mathrm{m} \mathrm{L}^{-1}\right)$.

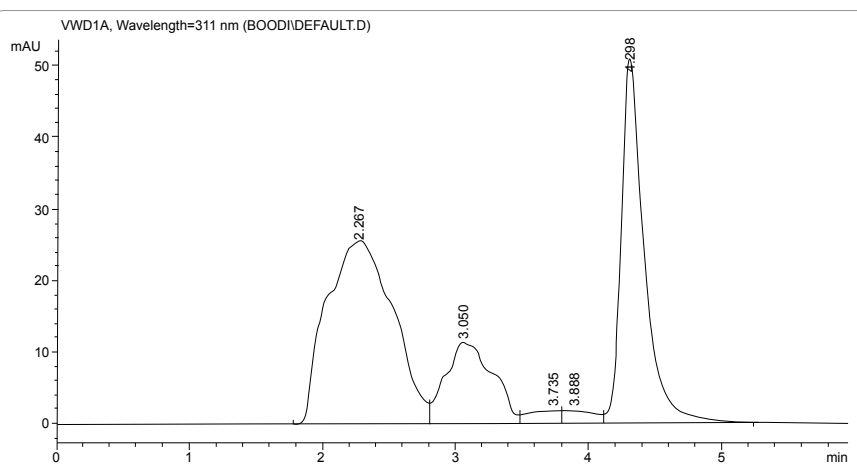

Figure 13: $\mathrm{HPLC}$ chromatogram of a resolved mixture of $10 \mu \mathrm{g} \mathrm{mL}^{-1} \mathrm{OZ}\left(\mathrm{t}_{\mathrm{R}}=4.298\right)$ and $10 \mu \mathrm{g} \mathrm{mL}^{-1} \mathrm{OZ} \mathrm{Deg}\left(\mathrm{t}_{\mathrm{R}}=2.267\right.$ and 3.050), mobile phase is acetonitrile: water (50:50 v/v, $0.2 \%$ triethylamine, $\mathrm{pH}$ adjusted to 4 using o-phosphoric acid).

\begin{tabular}{|l|c|c|c|}
\hline Parameters & OZ & Deg & limit \\
\hline Retention time $\mathbf{( t}_{\mathbf{R}}$ ) & 4.298 & 3.050 & \\
\hline Resolution ( $\mathbf{R})$ & 5.16 & & $\mathrm{Rs}>2$ \\
\hline Tailing factor (T) & 1.17 & & $\mathrm{~T}<2$ \\
\hline Capacity factor (K') & 9.745 & 6.625 & $1<\mathrm{K}^{\prime}<10$ \\
\hline Selectivity factor $(\mathbf{\alpha})$ & 1.471 & & $\mathrm{\alpha}>1$ \\
\hline Column efficiency (N) & 9552.59 & 1575.114 & $\mathrm{~N}>2000$ \\
\hline $\begin{array}{l}\text { Height equivalent to theoretical plate } \\
\text { (HETP) }\end{array}$ & 0.026 & 0.159 & \\
\hline
\end{tabular}

Table 2: System suitability parameters of the proposed HPLC method.

(50:50, v/v) best resolution was obtained upon using acetonitrile: water (50:50, v/v, 0.2\% triethylamine, $\mathrm{pH}$ adjusted to 4 using O-phosphoric

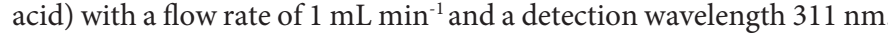

Upon applying the previously described HPLC optimum experimental conditions, good and efficient separation was observed between $\mathrm{OZ}$ and its degradation product (Figure 13).

Linear relationship was obtained for OZ between the relative peak areas and the corresponding concentrations. The regression equation was computed and found to be:

$$
\mathrm{A}=0.1334 \mathrm{C}-0.0318 \mathrm{r}=0.9998
$$

Where, $\mathrm{A}$ is the relative peak area, $\mathrm{C}$ is $\mathrm{OZ}$ concentration in $\mu \mathrm{g} \mathrm{mL}^{-1}$ and $\mathrm{r}$ is the correlation coefficient.

System suitability was checked by calculating different parameters such as capacity factor, tailing factor, column efficiency $(\mathrm{N})$, selectivity and resolution factors, where the system was found to be suitable relative to the reference values as shown in table 2 .

The proposed HPLC method was successfully applied for the determination of $\mathrm{OZ}$ in pure powdered form with mean percentage recovery of $100.00 \pm 1.302 \%$.

The specificity of the $\mathrm{D}^{1}, \mathrm{DD}^{1}$ and $\mathrm{MCR}$ methods was proved by the analysis of laboratory prepared mixtures containing different ratios of $\mathrm{OZ}$ and its degradate and satisfactory results were obtained for $\mathrm{OZ}$ in presence of degradate up to $80 \%$ (Table 3 ).

The four proposed methods have been successfully applied for the determination of OZ in Tibezole tablets. The validity of the methods was further assessed by applying the standard addition technique, (Table 4).

\begin{tabular}{|c|c|c|c|c|c|c|c|c|c|c|c|c|}
\hline \multirow{4}{*}{$\begin{array}{l}\text { Mixture } \\
\text { No. }\end{array}$} & \multirow{4}{*}{ Degradate \% } & \multirow{4}{*}{$\begin{array}{l}\text { Taken } \\
\text { OZ } \\
\text { g mL }^{-1}\end{array}$} & \multicolumn{4}{|c|}{$D^{1}$ method } & \multicolumn{4}{|c|}{$D^{1}$ method } & \multirow{2}{*}{\multicolumn{2}{|c|}{$\begin{array}{l}\text { MCN method } \\
\mathrm{OZ}\left(\mu \mathrm{g} \mathrm{mL} \mathrm{L}^{-1}\right)\end{array}$}} \\
\hline & & & \multicolumn{4}{|c|}{$\mathrm{OZ}\left(\mu \mathrm{g} \mathrm{mL} \mathrm{L}^{-1}\right)$} & \multicolumn{4}{|c|}{$\mathrm{OZ}\left(\mu \mathrm{g} \mathrm{mL} \mathrm{L}^{-1}\right)$} & & \\
\hline & & & \multicolumn{2}{|c|}{ At $290.4 \mathrm{~nm}$} & \multicolumn{2}{|c|}{ At $332 \mathrm{~nm}$} & \multicolumn{2}{|c|}{ At $288.5 \mathrm{~nm}$} & \multicolumn{2}{|c|}{ At $328 \mathrm{~nm}$} & \multicolumn{2}{|c|}{ At $312.8 \mathrm{~nm}$} \\
\hline & & & Found & Recovery \% & Found & Recovery \% & Found & Recovery \% & Found & Recovery \% & Found & Recovery \% \\
\hline 1 & 10 & 27 & 27.31 & 101.15 & 27.39 & 101.44 & 27.01 & 100.04 & 26.80 & 99.26 & 27.31 & 99.75 \\
\hline 2 & 20 & 24 & 24.42 & 101.75 & 24.23 & 100.96 & 24.07 & 100.29 & 24.38 & 101.58 & 24.42 & 98.88 \\
\hline 3 & 30 & 21 & 21.23 & 101.10 & 21.31 & 101.48 & 21.35 & 101.67 & 21.12 & 100.57 & 21.23 & 99.42 \\
\hline 4 & 40 & 18 & 18.24 & 101.33 & 18.23 & 101.28 & 18.28 & 101.56 & 18.28 & 101.56 & 18.24 & 99.04 \\
\hline 5 & 50 & 15 & 15.14 & 100.93 & 15.14 & 100.93 & 15.16 & 101.07 & 15.18 & 101.20 & 15.14 & 99.22 \\
\hline 6 & 60 & 12 & 12.05 & 100.42 & 12.23 & 101.92 & 12.14 & 101.17 & 12.11 & 100.92 & 12.05 & 101.00 \\
\hline 7 & 70 & 9 & 9.06 & 100.67 & 9.14 & 101.56 & 9.16 & 101.78 & 9.07 & 100.78 & 9.06 & 100.21 \\
\hline 8 & 80 & 6 & 6.07 & 101.17 & 6.06 & 101.00 & 6.09 & 101.50 & 6.05 & 100.83 & 6.07 & 98.29 \\
\hline $\begin{array}{l}\text { Mean } \\
\text { RSD\% }\end{array}$ & & & & $\begin{array}{l}101.07 \\
0.401\end{array}$ & & $\begin{array}{l}101.32 \\
0.343\end{array}$ & & $\begin{array}{l}101.14 \\
0.640\end{array}$ & & $\begin{array}{l}100.84 \\
0.728\end{array}$ & & $\begin{array}{l}99.48 \\
0.845\end{array}$ \\
\hline
\end{tabular}

Table 3: Determination of $\mathrm{OZ}$ in presence of its degradate in laboratory prepared mixtures by the $\mathrm{D}^{1}, \mathrm{DD}^{1} \mathrm{MCN}$ methods. 
Citation: Khattab FI, Ramadan NK, Hegazy MA, Ghoniem NS (2012) Stability-Indicating Methods for the Determination of Ornidazole in The Presence of its Degradate According to ICH Guidelines. Pharmaceut Anal Acta 3:179. doi:10.4172/2153-2435.1000179

Page 7 of 8

\begin{tabular}{|c|c|c|c|c|c|c|c|c|c|c|c|c|}
\hline \multirow[t]{3}{*}{ Parameter } & \multicolumn{4}{|c|}{$\mathrm{D}^{1}$ method } & \multicolumn{4}{|c|}{$\mathrm{DD}^{1}$ method } & \multirow{2}{*}{\multicolumn{2}{|c|}{$\begin{array}{l}\text { MCR method } \\
\text { At } 312.8 \mathrm{~nm}\end{array}$}} & \multirow{2}{*}{\multicolumn{2}{|c|}{ HPLC method }} \\
\hline & \multicolumn{2}{|c|}{ At $290.4 \mathrm{~nm}$} & \multicolumn{2}{|c|}{ At $332 \mathrm{~nm}$} & \multicolumn{2}{|c|}{ At $288.5 \mathrm{~nm}$} & \multicolumn{2}{|c|}{ At $328 \mathrm{~nm}$} & & & & \\
\hline & $\begin{array}{l}\text { Found } \\
\%{ }^{a}\end{array}$ & $\begin{array}{l}\text { Recovery } \\
\text { of standard } \\
\text { added } \% \text { b }\end{array}$ & $\begin{array}{c}\text { Found } \\
\%^{a}\end{array}$ & $\begin{array}{l}\text { Recovery } \\
\text { of standard } \\
\text { added } \%^{\mathrm{b}}\end{array}$ & $\begin{array}{l}\text { Found } \\
\%^{a}\end{array}$ & $\begin{array}{l}\text { Recovery } \\
\text { of standard } \\
\text { added } \%{ }^{\mathrm{b}}\end{array}$ & $\begin{array}{l}\text { Found } \\
\%{ }^{a}\end{array}$ & $\begin{array}{l}\text { Recovery } \\
\text { of standard } \\
\text { added } \% \text { b }\end{array}$ & $\begin{array}{l}\text { Found } \\
\%^{a}\end{array}$ & $\begin{array}{l}\text { Recovery } \\
\text { of standard } \\
\text { added } \%^{c}\end{array}$ & $\begin{array}{l}\text { Found } \\
\%^{a}\end{array}$ & $\begin{array}{l}\text { Recovery } \\
\text { of standard } \\
\text { added } \%^{c}\end{array}$ \\
\hline $\begin{array}{l}\text { Tibezole }{ }^{\circledR} \\
\text { tablets } 500 \\
\text { mg OZ/tablet } \\
\text { B.N.1319003 }\end{array}$ & $\begin{array}{l}99.90 \pm \\
1.032\end{array}$ & $\begin{array}{l}101.12 \\
\pm \\
0.629\end{array}$ & $\begin{array}{l}100.86 \pm \\
0.954\end{array}$ & $\begin{array}{l}100.17 \\
\pm \\
0.606\end{array}$ & $\begin{array}{l}100.62 \pm \\
0.452\end{array}$ & $\begin{array}{l}100.87 \\
\pm \\
0.300\end{array}$ & $\begin{array}{l}99.88 \pm \\
0.501\end{array}$ & $\begin{array}{l}98.91 \\
\pm \\
0.600\end{array}$ & $\begin{array}{l}98.40 \pm \\
1.204\end{array}$ & $\begin{array}{l}97.72 \\
\pm \\
0.648\end{array}$ & $\begin{array}{l}100.97 \pm \\
0.504\end{array}$ & $\begin{array}{l}100.74 \\
\pm \\
0.372\end{array}$ \\
\hline
\end{tabular}

${ }^{a}$ Average of four determinations

${ }^{\mathrm{b}}$ Average of four determinations

${ }^{\mathrm{c} A v e r a g e}$ of three determinations

Table 4: Results obtained by applying the proposed methods for the determination of OZ in Tibezole ${ }^{\circledR}$ tablets and results obtained by applying standard addition technique

\begin{tabular}{|c|c|c|c|c|c|c|c|}
\hline \multirow{2}{*}{ Parameter } & \multicolumn{2}{|l|}{$D^{1}$ method } & \multicolumn{2}{|l|}{$\mathrm{DD}^{1}$ method } & \multirow{2}{*}{ MCR method } & \multirow{2}{*}{ HPLC method } & \multirow{2}{*}{$\begin{array}{l}{ }^{* *} \text { Reported } \\
\text { method }\end{array}$} \\
\hline & At $290.4 \mathrm{~nm}$ & At $332 \mathrm{~nm}$ & At $288.5 \mathrm{~nm}$ & At $328 \mathrm{~nm}$ & & & \\
\hline Mean & 99.9 & 100.86 & 100.62 & 99.88 & 98.40 & 100.97 & 99.78 \\
\hline SD & 1.031 & 0.962 & 0.455 & 0.500 & 1.185 & 0.509 & 0.852 \\
\hline n & 4 & 4 & 4 & 4 & 4 & 4 & 4 \\
\hline Variance & 1.063 & 0.925 & 0.207 & 0.250 & 1.404 & 0.259 & 0.726 \\
\hline Student's t & $0.137(2.45)^{\star}$ & $1.284(2.45)^{\star}$ & $1.328(2.45)^{*}$ & $0.155(2.45)^{\star}$ & $1.44(2.45)^{*}$ & $1.028(2.45)^{\star}$ & \\
\hline$F$ & $\begin{array}{l}1.464 \\
(9.2766)^{*}\end{array}$ & $1.274(9.2776)^{*}$ & $\begin{array}{l}3.507 \\
(9.2766)^{*}\end{array}$ & $\begin{array}{l}2.904 \\
(9.2776)^{*}\end{array}$ & $1.934(9.2776)^{*}$ & $\begin{array}{l}2.803 \\
(9.2776)^{*}\end{array}$ & \\
\hline
\end{tabular}

* The values in parentheses are the corresponding tabulated values at $p=0.05$.

${ }^{* *}$ HPLC method (C-18, using acetonitrile: water 38:62 v/v consisting of triethylamine and adjusted to $\mathrm{pH} 3.6$ with $5 \%$ O-phosphoric acid, flow rate $0.8 \mathrm{~mL}$ min $\left.{ }^{1}, 254 \mathrm{~nm}\right)$.

Table 5: Statistical comparison of the results obtained by the proposed methods and the reported HPLC Method [25] for the analysis of OZ in Tibezole ${ }^{\circledR}$ tablets.

The results obtained for the analysis of $\mathrm{OZ}$ in its pharmaceutical dosage form were statistically compared with those obtained by applying a reported method [24]. The values of calculated $\mathrm{t}$ and $\mathrm{F}$ are less than the tabulated ones, which reveals that there is no significant difference between the two methods with respect to accuracy and precision (Table 5)

The repeatability and intermediate precision was evaluated by assaying freshly prepared solutions of the drug in triplicate on the same day and on three successive days respectively at concentrations of 10,20 , and $30 \mu \mathrm{g} / \mathrm{ml}$ for the $\mathrm{D}^{1}, \mathrm{DD}^{1}$ and $\mathrm{MCN}$ methods and at concentrations 4,8 , and $12 \mu \mathrm{g} / \mathrm{ml}$ for the HPLC method. RSD\% (Table 1) showed the precision and the ruggedness of the methods.

Validation [25] of the proposed methods was constructed by determining the linearity, range, accuracy and precision (Table 1).

\section{References}

1. Harvey RA, Champe PC, Mycek MJ (2006) Pharmacology. (4thedn), Lippincott Williams \& Wilkins 187-214

2. Sweetman S (2009) Martindale: The Complete Drug Reference. (26thedn) The Pharmaceutical Press.

3. Visan V, lonescu MS, Dragos M, Belu D, Cosofret V (1989) Rev Chim (Bucharest) 40: 728-731.

4. Hassan MM, Jado Al, El-shazly BM (1989) Spectrosc. Lett 22: 111-121.

5. Bugaj A, Marciniec B (1994) Determination of nitroimidazoles in the solidstate by infrared spectrophotometric method. Chemical Analysis (Warsaw) 39: $705-711$

6. Patel SA, Prajapati AM, Patel PU, Patel NJ, Vaghmasi JB (2008) Development and validation of column high-performance liquid chromatographic and derivative spectrophotometric methods for determination of levofloxacin and ornidazole in combined dosage forms. J AOAC Int 91: 756-761.

7. Róna K, Gachálvi B (1987) Simple liquid chromatographic method for the determination of ornidazole and metronidazole in human serum. J Chromatogr 420: 228-230.
8. Groppi A, Papa P, Montagna M, Carosi G (1986) Determination of ornidazole in human plasma and red blood cells using high-performance liquid chromatography. J Chromatogr 380: 437-442.

9. Heizmann P, Geschke R, Zinapold K (1990) Determination of ornidazole and its main metabolites in biological fluids. J Chromatogr 534: 233-240.

10. Bakshi M, Singh B, Singh A, Singh S; International Conference on Harmonization (2001) The ICH guidance in practice: stress degradation studies on ornidazole and development of a validated stability-indicating assay. J Pharm Biomed Anal 26: 891-897.

11. Liang XQ, Shi T (2002) Zhongguo Yiyao Gongye Zazhi 33: 93-94

12. Lu Y, Peng J, Tan HS (2006) Yaowu Fenxi Zazhi 26: 1503-1505

13. Huang JQ, Xu QL, Cao GY, Hu X, Sun CH, et al. (2007) 27: 532-534.

14. Sun HW, Wang FC, Ai LF (2007) Simultaneous determination of seven nitroimidazole residues in meat by using HPLC-UV detection with solid-phase extraction. J Chromatogr B Analyt Technol Biomed Life Sci 857: 296-300.

15. Ranjane PN, Gandhi SV, Kadukar SS, Ranher SS (2008) Simultaneous determination of cefuroxime axetil and ornidazole in tablet dosage form using reversed-phase high performance liquid chromatography. Se Pu 26: 763765

16. Suhagia BN, Shah SA, Rathod IS, Patel HM, Shah DR, et al. (2006) Determination of gatifloxacin and ornidazole in tablet dosage forms by highperformance thin-layer chromatography. Anal Sci 22: 743-745.

17. Chepurwar SB, Shirkhedkar AA, Bari SB, Fursule RA, Surana SJ (2007) Validated HPTLC method for simultaneous estimation of levofloxacin hemihydrate and ornidazole in pharmaceutical dosage form. J Chromatogr Sci 45: 531-536.

18. Liu B, Huang WH, Wang JZ (2008) Fenxi Kexue Xuebao: 24: 586-588.

19. Sankar PS, Reddy JS (1989) Indian J Environ Prot 9: 589-591.

20. Warowna W, Fijalek Z, Dziekanska A, Korzeniewska A (1991) Acta Poloniae Pharmaceutica 48: 17-21.

21. Fonseca JM, Rivera MC, Monteagudo JC (1993) Anal Lett 26: 109-124. 
Citation: Khattab FI, Ramadan NK, Hegazy MA, Ghoniem NS (2012) Stability-Indicating Methods for the Determination of Ornidazole in The Presence of its Degradate According to ICH Guidelines. Pharmaceut Anal Acta 3:179. doi:10.4172/2153-2435.1000179

Page 8 of 8

22. Lv Y, Zhang Z, He D, Hu Y (2003) Flow-injection determination of ornidazole by chemiluminescence detection based on a luminol-ferricyanide reaction. Anal Sci 19: 625-627.

23. Salman A, Sumer C (1996) Sci Pharm 64: 145-149.
24. Krishnaiah YS, Muzib YI, Bhaskar P, Shyale SS (2003) Asian J Chem 15: 925-929.

25. International conference of harmonization of technical requirements for regestiration of pharmaceuticals for human use $(\mathrm{ICH})$. 